\title{
Effect of Heat Stress and the Recovery Potential of Heterocystous Cyanobacterium, Anabaena iyengarii Bharadwaja 1935
}

\author{
Sidhartha Kumar Dash ${ }^{1,2}$, Jitendra Kumar Pandey, Mrutyunjay Jena2* (if \\ and Basanti Biswal ${ }^{1}$ \\ ${ }^{1}$ Laboratory of Biochemistry and Molecular Biology, School of Life Sciences, Sambalpur University, Jyotivihar - \\ 768 019, Odisha, India. \\ ${ }^{2}$ Algal Biotechnology and Molecular Systematic Laboratory, Department of Botany, Berhampur University, \\ Bhanja Bihar - 760 007, Odisha, India.
}

\begin{abstract}
Cyanobacteria, the major photosynthetic organisms, cover a large surface area of this planet. These organisms, being photosynthetic, have the capacity for sequestration of atmospheric carbon dioxide, a significant greenhouse gas that causes global warming. In this work, we have collected, developed pure culture, and identified $\mathbf{2 5}$ cyanobacterial species from semi arid agricultural rice fields of western Odisha with the high-temperature environmental setting. The purpose was to screen the cyanobacteria that can survive and grow at high temperatures with high photosynthetic efficiency. Cyanobacteria belong to genera Nostoc, Anabaena, Calothrix, and Hapalosiphon are observed to survive at $45^{\circ} \mathrm{C}$. Among the cyanobacterial species, Anabaena iyengarii 17-SKD-2014 was found to exhibit higher growth, protein content, photosynthetic pigments, and photosynthetic $\mathrm{O}_{2}$ evolution at $45^{\circ} \mathrm{C}$ in comparison to other cyanobacterial isolates. Further, this cyanobacterium was grown at $50^{\circ} \mathrm{C}$ to analyze the cellular viability, and only up to ninth day incubated culture could recover from high-temperature stress after transferring to $25^{\circ} \mathrm{C}$. Even though this indigenous cyanobacterial species failed to survive at $50^{\circ} \mathrm{C}$ in the laboratory conditions beyond a time limit, but this could be biotechnologically manipulated for effective carbon dioxide sequestration contributing to minimization of global warming.
\end{abstract}

Keywords: Cyanobacteria, Anabaena, stress, photosynthesis

*Correspondence: mrutyunjay.jena@gmail.com; +91 7894060760

(Received: August 05, 2020; accepted: December 02, 2020)

Citation: Dash SK, Pandey JK, Jena M, Biswal B. Effect of Heat Stress and the Recovery Potential of Heterocystous Cyanobacterium, Anabaena iyengarii Bharadwaja 1935. J Pure Appl Microbiol. 2020;14(4):2467-2476. doi: 10.22207/JPAM.14.4.24

(C) The Author(s) 2020. Open Access. This article is distributed under the terms of the Creative Commons Attribution 4.0 International License which permits unrestricted use, sharing, distribution, and reproduction in any medium, provided you give appropriate credit to the original author(s) and the source, provide a link to the Creative Commons license, and indicate if changes were made. 


\section{INTRODUCTION}

Cyanobacteria, the most diversified microorganisms, inhabit terrestrial as well as aquatic environments. They are widely distributed in various environments, ranging from hot springs, volcanic islands ${ }^{1}$, hot deserts ${ }^{2}$, sandy soils ${ }^{3}$, highaltitude rivers, lakes, and $\operatorname{seas}^{4-6}$ to fresh-water ecosystems ${ }^{7}$. Cyanobacteria experience different levels and types of stress in their natural habitats. Therefore, necessary to study the adaptive and tolerance mechanisms they develop in response to changing stress conditions $s^{8,9}$. These microorganisms can acclimatize their growth to various environmental pressures with specific changes in their morphology, metabolism, and genetic makeup ${ }^{10-13}$. Global warming and the current environmental scenario increase the importance of temperature as one of the major stress factors that could be examined to understand the survival strategy of these microorganisms.

The response and acclimation towards heat stress are species-dependent. Cyanobacteria may experience short- and long-term stress periods, and they accordingly respond to the pressure by modifying their cellular metabolic strategies. Short-term strategies include alteration of the photosynthetic light-harvesting complex ${ }^{14,15}$, cytoplasmic and thylakoid membrane mobility ${ }^{16,17}$ and reversible modification of enzymes. In contrast, long-term strategies may reveal gene expression patterns, cell metabolism, and structural modification ${ }^{18-20}$. Very little is known about the distribution, diversity, and versatility of cyanobacteria in the dry sub-humid region of India. The Growth, resistance to high temperature, and survival strategy of specific cyanobacterial species are not widely known. Most of the earlier reports have focused on the physiological and molecular aspects of heat stress, specifically in thermophilic cyanobacteria, with a short duration of the stress period. Among cyanobacterial species, heterocytous nitrogen-fixing cyanobacteria, such as Aulosira, Cylindrospermum, Nostoc, Anabaena, Tolypothrix, and Calothrix, are prolific under waterlogging conditions in rice fields ${ }^{21}$. A total 58 cyanobacterial species belonging to 20 genera from which 19 isolates were of heterocytous form are reported in the rice fields of Odisha, India ${ }^{22}$. In the present work, we have examined the distribution and thermo-tolerance of mesophilic indigenous cyanobacteria found in the paddy fields of Western Odisha. We aimed to explore the extent to which these indigenous cyanobacteria can survive under severe heat stress and the recovery potential of the heat stressed microorganisms upon their transfer to favorable temperatures in the laboratory.

\section{MATERIALS AND METHODS \\ Experimental design}

The heterocystous cyanobacterial species were isolated from the rice fields of Western Odisha. Only filamentous nitrogenfixing cyanobacterial cultures were screened and maintained in a combined nitrogen-free BG11 medium, and the experiments were performed by using the batch culturing method. The exponentially growing (7-10 days) cyanobacterial cultures were harvested, and the initial cell mass was maintained at 0.04 O.D. for the experiment. The samples were aliquoted with freshly prepared nitrogen-free BG11 medium and incubated under continuous cool white-light illumination with an irradiance of $42 \mu \mathrm{mol} \mathrm{m} \mathrm{m}^{-2} \mathrm{~s}^{-1}$. A total incubation period of 15 days was set for each cyanobacterial strain at defined temperatures of $25^{\circ} \mathrm{C}, 35^{\circ} \mathrm{C}$, $40^{\circ} \mathrm{C}$, and $45^{\circ} \mathrm{C}$. On every third day, the respective cyanobacterium culture flask was taken out from the BOD incubator for further biochemical analysis. Each of the batch cultures was pre-acclimatized at lesser than $5^{\circ} \mathrm{C}$ for ten days before placing in respective heat stress conditions. Cellular recovery was observed after a fixed mass of four selected cyanobacterial cultures was incubated at $50^{\circ} \mathrm{C}$ for 15 days. Cultures were harvested every third day from the $50^{\circ} \mathrm{C}$ grown samples and incubated at $25^{\circ} \mathrm{C}$. These retrieved samples were regrown for further biochemical analysis. Every third day, each culture flask was retrieved and placed under standard growth conditions to observe the periodic recovery. All the above-mentioned experiments were conducted in triplicate.

\section{Measurement of growth}

The growth of cyanobacterial isolates was monitored using a light-scattering technique by recording the absorbance at $760 \mathrm{~nm}$ by a UV-visible spectrophotometer (Cary 50 Bio, Varian, Australia). The samples were thoroughly homogenized and appropriately shaken before recording. 
Measurement of chlorophyll-a and carotenoids

A fixed volume of culture was centrifuged, and the pellet was suspended in chilled aqueous acetone $(80 \%)$, as described by Myers and Kartz ${ }^{23}$. The suspension was incubated overnight at $4^{\circ} \mathrm{C}$ in dark conditions and centrifuged at 5000 RCF for 10 min to obtain a clear supernatant. The supernatant was used to estimate chlorophyll-a (663 nm.) and carotenoids $(460 \mathrm{~nm}$.) contents with extinction coefficients of 80.04 and 200, respectively.

\section{Extraction and estimation of phycobiliproteins}

Cyanobacterial cells were harvested by centrifugation ( $3000 \mathrm{RCF}$ for $15 \mathrm{~min}$ ). The biomass was homogenized with phosphate buffer $(0.05$ $\mathrm{M}, \mathrm{pH}$ 7.0) and subjected to repeated freezing $\left(-20^{\circ} \mathrm{C}\right)$ and thawing at room temperature $\left(25^{\circ} \mathrm{C}\right)$ in dark conditions. The mixture was subsequently centrifuged $\left(10000 \mathrm{RCF}\right.$ for $20 \mathrm{~min}$ at $\left.4^{\circ} \mathrm{C}\right)$ to separate the phycobilins in the supernatant. The absorbance of the supernatant was measured using the UV-visible spectrophotometer at wavelengths 615,652 , and $562 \mathrm{~nm}$. Contents of Phycocyanin (PC), Allophycocyanin (APC), and Phycoerythrin (PE) were calculated using the following equations ${ }^{24}$ :

- $\quad \mathrm{PC}\left(\mathrm{mg} \mathrm{mL}^{-1}\right)=[\mathrm{A} 615-0.474(\mathrm{~A} 652)] / 5.34$

- $\quad \operatorname{APC}\left(\mathrm{mg} \mathrm{mL}^{-1}\right)=[\mathrm{A} 652-0.208(\mathrm{~A} 620)] / 5.09$

- $\quad P E(m g ~ m L-1)=[A 562-2.41(P C)-0.849$ (APC)]/9.62

\section{Estimation of protein}

Total protein was quantified from the samples according to the method of Lowry et al. ${ }^{25}$. The residue left after the extraction of chlorophyll-a and carotenoid was precipitated with $5 \mathrm{ml}$ of $6 \%$ trichloroacetic acid. The pellet was dissolved in protein reagent and kept for incubation at room temperature for $30 \mathrm{~min}$. Then the solution was heated at $100^{\circ} \mathrm{C}$ for $5 \mathrm{~min}$,

Table 1. List of cyanobacteria isolated from paddy fields of Western Odisha and their survivability under high temperature stress $\left(45^{\circ} \mathrm{C}\right)$. The isolated cyanobacterial $16 \mathrm{~S}$ rRNA genes are submitted under the given accession number. Each of the isolates were treated for their survivability under high temperature $\left(45^{\circ} \mathrm{C}\right)$ for a duration of 15 days

\begin{tabular}{llc}
\hline Accession No. & Strains isolated & Survived at $45^{\circ} \mathrm{C}$ \\
\hline LC011912 & Nostoc carneum isolate: 1 & - \\
LC011913 & Nostoc ellipsosporum isolate: 3 & + \\
LC011914 & Calothrix javanica isolate: 4 & + \\
LC011915 & Calothrix marchica isolate: 5 & + \\
LC011969 & Nostoc punctiforme isolate: 6-SKD-2014 & - \\
LC011970 & Hapalosiphon welwitschii 7-SKD-2014 & + \\
LC011971 & Calothrix sp. 8-SKD-2014 & - \\
LC011972 & Calothrix sp. 9-SKD-2014 & - \\
LC011973 & Anabaena variabilis isolate:10-SKD-2014 & + \\
LC011978 & Nostoc parmelioides 11-SKD-2014 & - \\
LC011985 & Calothrix sp. 13-SKD-2014 & - \\
LC011979 & Nostoc sp. 14-SKD-2014 & - \\
LC011980 & Nostoc sp. 16-SKD-2014 & - \\
LC011974 & Anabaena iyengarii isolate: 17-SKD-2014 & + \\
LC011975 & Anabaena anomala isolate: 18-SKD-2014 & + \\
LC011987 & Nostoc oryzae 19-SKD-2014 & + \\
LC011976 & Anabaena orientalis isolate: 20-SKD-2014 & + \\
LC011981 & Desmonostoc muscorum isolate: 21-SKD-2014 & - \\
LC011986 & Calothrix weberi 22-SKD-2014 & - \\
LC011977 & Anabaena torulosa isolate: 23-SKD-2014 & + \\
LC011982 & Nostoc calcicola isolate: 24-SKD-2014 & + \\
LC011983 & Nostoc sp. 25-SKD-2014 & - \\
LC011984 & Nostoc sp. 26-SKD-2014 & + \\
LC011988 & Nostoc oryzae 28-SKD-2014 & - \\
LC011989 & Nostoc oryzae 29-SKD-2014 & + \\
\hline
\end{tabular}


followed by centrifugation at 6000 RCF for $10 \mathrm{~min}$ to obtain a clear supernatant. The Folin-Ciocalteu reagent was added to the supernatant rapidly, shaken, and kept for $30 \mathrm{~min}$ at room temperature. Absorbance was recorded at $750 \mathrm{~nm}$ against an appropriate reference. Bovine serum albumin (BSA) was taken as a standard.

\section{Measurement of oxygen evolution}

Oxygen evolution was measured in a DW2/2 liquid-phase electrode chamber (Chlorolab 2, Hansatech, King's Lynn, Norfolk, UK) according to the method of Jiang and Qiur26. Oxygen measurement was controlled by an OXYL1 Oxylab Control Unit. Liquid samples were used under automated illumination with red (660 $\mathrm{nm}$ ) LED light. A light intensity of $300 \mu \mathrm{mol} \mathrm{m} \mathrm{m}^{-2} \mathrm{~s}^{-1}$ was used for a higher rate of oxygen evolution. One milliliter of the homogenized cyanobacterial sample was taken in the electrode chamber. Changes in oxygen content of the sample were determined by the integral oxygen electrode mounted at the base of the chamber (Hansatech). The rate of oxygen evolution was measured in $\mu \mathrm{mol} \mathrm{O}_{2} \mathrm{~min}^{-1}$.

\section{Data analysis}

Comparisons between variables were made by one-way analysis of variance (ANOVA) followed by Duncan's multiple ranges and homogeneity test. Calculation and statistical analysis were performed using MS Excel 2007 and SPSS 16.0 for Windows. P-values $<0.05$ were considered significant.

\section{RESULTS}

Screening of cyanobacterial strains for their survivability under high-temperature stress $\left(45^{\circ} \mathrm{C}\right)$

Twenty-five axenic cyanobacterial isolates belonging to four genera, namely Anabaena, Nostoc, Calothrix, and Hapalosiphon, predominantly found in paddy fields, were subjected to high-temperature treatment $\left(45^{\circ} \mathrm{C}\right)$ for 15 days (Table 1) to observe their visible survivability and it was noted that 12 different isolates could tolerate the heat. Of these 12 isolates, four isolates, namely Anabaena iyengarii 17-SKD-2014, Nostoc oryzae 19-SKD-2014, Nostoc sp. 25-SKD-2014, and Nostoc sp. 26SKD-2014 were selected for further tests. These cyanobacteria were found to have maximum cell density under standard culture conditions, i.e., at $25^{\circ} \mathrm{C}$. Further, Anabaena iyengarii 17-SKD-2014 was selected based on a higher growth rate at $45^{\circ} \mathrm{C}$ and photosynthetic activity was analyzed under differential temperature conditions.

\section{Effect of heat stress on growth}

Effect of temperature on cell density of the four cyanobacterial isolates were elicided in the present investigation. The line graph indicates a gradual increase in cellular mass when there is an increase in temperature from $25^{\circ} \mathrm{C}$ to $40^{\circ} \mathrm{C}$ for all the four species with a decline thereafter at $45^{\circ} \mathrm{C}$. All the above isolates achieved maximum growth at an optimum temperature (i.e., $40^{\circ} \mathrm{C}$ ),
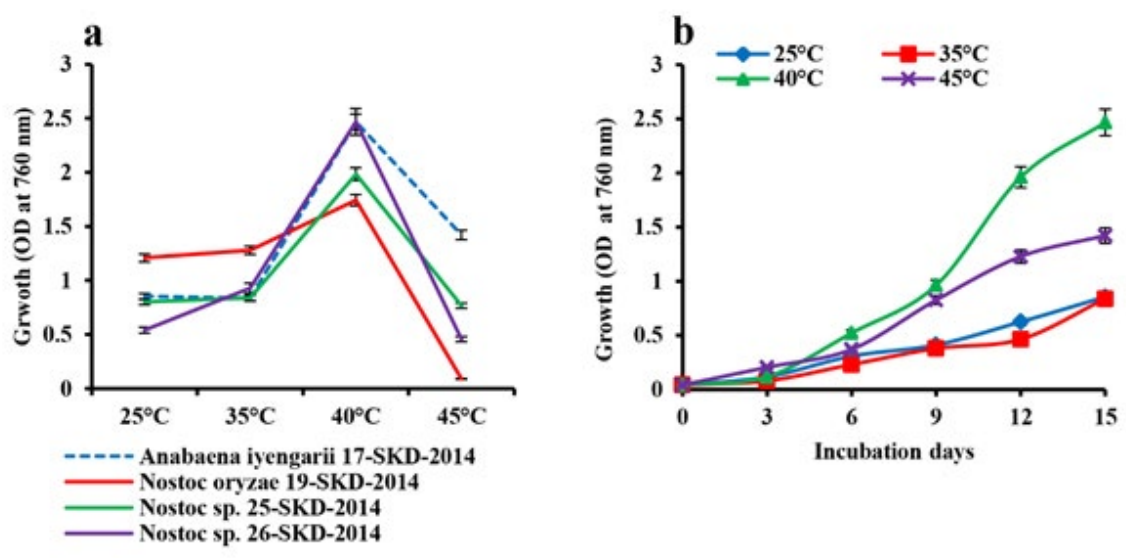

Fig. 1. Changes in the growth with response to heat stress. (a) Growth curve of cyanobacterial isolates on the 15th day culture, (b) Growth of Anabaena iyengarii 17-SKD-2014 at different temperatures from the 0th to 15th day of culture. Each value represents the mean of three independent estimates \pm S.D. 
although the cyanobacterial species $A$. iyengarii 17-SKD-2014 and Nostoc sp. 26-SKD-2014 exhibited maximum growth at $40^{\circ} \mathrm{C}$. The decline in the growth rate of $A$. iyengarii at $45^{\circ} \mathrm{C}$ was much less than other cyanobacterial isolates (Fig.1a). Further, this species was selected to analyze the total protein content, photosynthetic pigments content and oxygen evolution efficiency under differential temperature conditions.

In adition, the effect of heat stress on the growth rate of $A$. iyengarii was measured upto $15^{\text {th }}$ day on every 3 rd day of culture. A steady increase in growth was found at all temperatures, but more significant growth was observed at $40^{\circ} \mathrm{C}$ (Fig. 1b). Though, there was no significant difference in cell density in the culture growth at $25^{\circ} \mathrm{C}$ and $35^{\circ} \mathrm{C}$.

Effect of heat stress on protein and pigment content

The changes in total protein content showed similar patterns of growth with a maximum of $1.7 \mathrm{mg} \mathrm{mL}^{-1}$ of protein at $40^{\circ} \mathrm{C}$ in the $15^{\text {th }}$ day culture (Fig. 2a). The changes in the pigments content of $A$. iyengarii in response to different temparure regimes were observed noticeably a

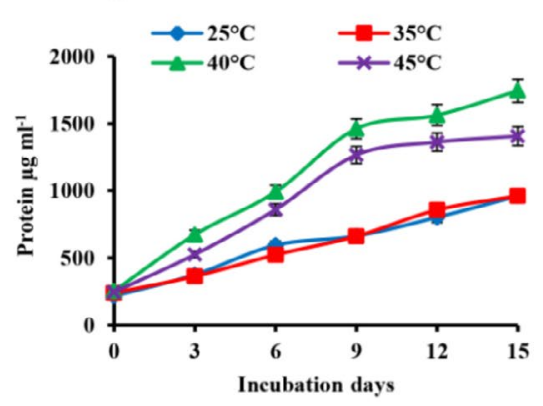

c

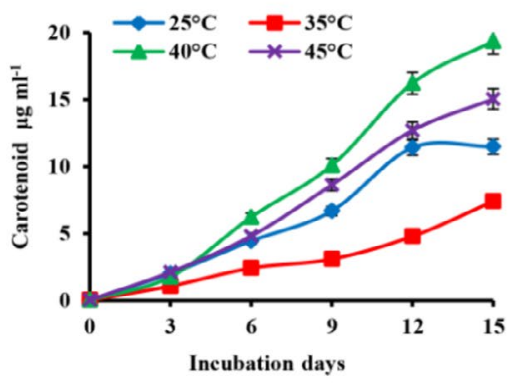

e

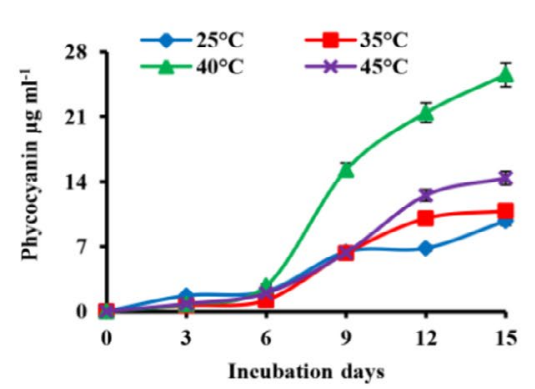

b

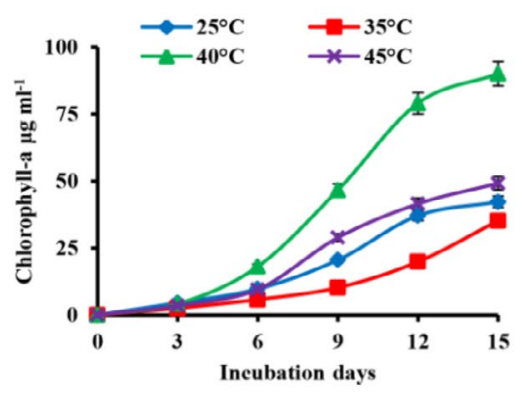

d

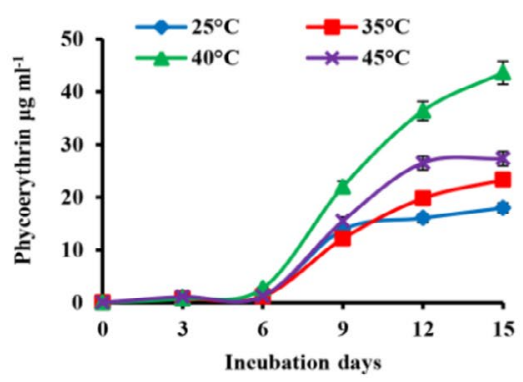

f

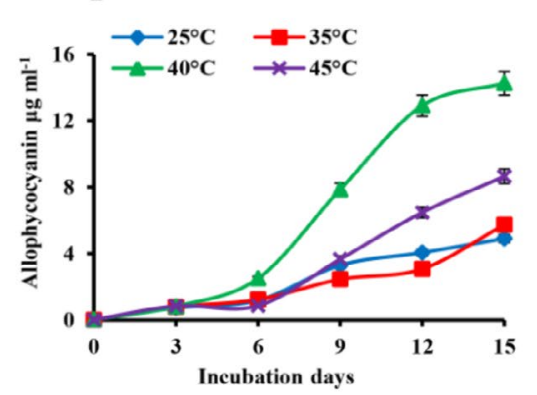

Fig. 2. Effect of heat stress in the changes in total protein and photosynthetic pigment contents of Anabaena iyengarii 17-SKD-2014 at different temperatures. (a) protein content, (b) chlorophyll-a, (c) carotenoid, (d) phycoerythrin, (e) phycocyanin and $(f)$ allophycocyanin. Data are the average of three different experiments \pm S.D. 


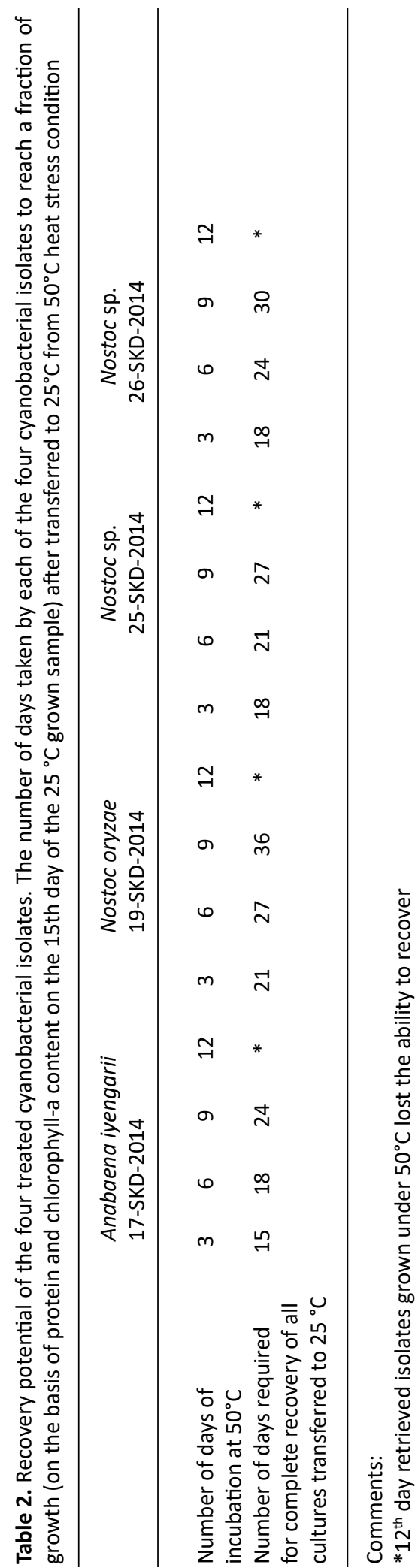

during the different days of incubation. The chlorophyll-a was found with a gradual rise until day 12 and reaching the stationary phase by day 15 and showed maximum concentrations at $40^{\circ} \mathrm{C}$ $(89.9 \mu \mathrm{g} \mathrm{mL}-1)$ and declined at $45^{\circ} \mathrm{C}(49.14 \mu \mathrm{g}$ $\mathrm{mL}^{-1}$ ), shown in the figure (Fig. 2b). The changes in carotenoid content were detected a similar pattern as chlorophyll-a, increasing with the rising of temperature and found highest at $40^{\circ} \mathrm{C}$ of 19.35 $\mu \mathrm{g} \mathrm{mL}{ }^{-1}$ and declined at $45^{\circ} \mathrm{C}\left(15.03 \mu \mathrm{g} \mathrm{mL}{ }^{-1}\right)$ (Fig. $2 \mathrm{c})$. Though there was a very minute difference in chlorophyll-a content between $25^{\circ} \mathrm{C}$ and $35^{\circ} \mathrm{C}$ in the $15^{\text {th }}$-day culture, carotenoids content was found to be higher at $25^{\circ} \mathrm{C}$ than $35^{\circ} \mathrm{C}$.

The effect of temperatures on phybilinprotiens i.e. phycoerythrin (PE), phycocyanin (PC), and allophycocyanin (APC) also noticed in the present investigation. A steady increase in the levels of phycobiliproteins contents under high temperature was observed until the $12^{\text {th }}$ day; afterward, the rate decreased and steadied up to the $15^{\text {th }}$ day. The individual pigments had a maximum content at $40^{\circ} \mathrm{C}$, shown in the Fig. $2 \mathrm{~d}, \mathrm{e}, \mathrm{f}$ of $\mathrm{PE}, \mathrm{PC}, \mathrm{APC}$ respectively.

\section{Photosynthetic $\mathrm{O}_{2}$ evolution}

The effect of temperature on the net oxygen evolution of $A$. iyengarii cells is shown in fig. 3 . There was a progressive increase in the net $\mathrm{O}_{2}$ evolution under four temperature conditions throughout the incubation periods. The changes in $\mathrm{O}_{2}$ between the temperatures until the $6^{\text {th }}$ day of culture were less, but after that, there was an increase in net $\mathrm{O}_{2}$ evolution till the $12^{\text {th }}$ day of culture followed by a steady-state on the $15^{\text {th }}$ day. The maximum photosynthetic $\mathrm{O}_{2}$ evolution was observed at $40^{\circ} \mathrm{C}$, followed by $45^{\circ} \mathrm{C}$ decreased from $0.289 \mu \mathrm{mol} \mathrm{min}{ }^{-1} \mathrm{~mL}^{-1}$ to $0.186 \mu \mathrm{mol} \mathrm{min}^{-1}$ $\mathrm{mL}^{-1}$ (Fig. 3).

Analysis of cellular regeneration efficiency

A. iyengarii was treated with high temperature at $50^{\circ} \mathrm{C}$ continuously for 15 days. During these days, their regeneration ability, chlorophyll-a, and total protein contents were studied (Fig 4 a \& b, Table 2). The high temperature was found to be harsh and ultimately resulted in a decline in the cellular growth and other biochemical parameters. The culture retrieved from the $3^{\text {rd }}$ day of severe heat stress was found to regain its growth in the next 15 days under incubation at $25^{\circ} \mathrm{C}$. Chlorophyll-a and total protein 
content at $50^{\circ} \mathrm{C}$ was found to decrease after day three continuously (Fig 3 a \& b). Further, the cells obtained from day six and day nine took longer durations to regenerate, i.e., 18 days and 24 days, respectively (Table 2 ). Heat-stressed cultures longer than nine days were found to be bleached and could not recover further. The maximum chlorophyll-a was found to be $40.58 \mu \mathrm{g} \mathrm{mL}^{-1}$, $41.25 \mu \mathrm{g} \mathrm{mL}^{-1}$ and $42.48 \mu \mathrm{g} \mathrm{mL}^{-1}$ from the $3^{\text {rd }}$ day, $6^{\text {th }}$ day and $9^{\text {th }}$-day heat-stressed cultures on the $15^{\text {th }}, 18^{\text {th }}$ and $24^{\text {th }}$ day, respectively, against the control sample at $25^{\circ} \mathrm{C}$, which had $42.22 \mu \mathrm{g} \mathrm{m}^{-1}$ of chlorophyll-a (Fig. 4 a). Similarly, the total protein content was found $953 \mu \mathrm{g} \mathrm{mL}^{-1}, 952 \mu \mathrm{g} \mathrm{mL} \mathrm{L}^{-1}$ and $962 \mu \mathrm{g} \mathrm{mL}^{-1}$ against the control of $960.6 \mu \mathrm{g} \mathrm{mL}^{-1}$ (Fig. 4b).

\section{DISCUSSION}

In Western Odisha, the summer temperature touches $45-47^{\circ} \mathrm{C}$ frequently, and

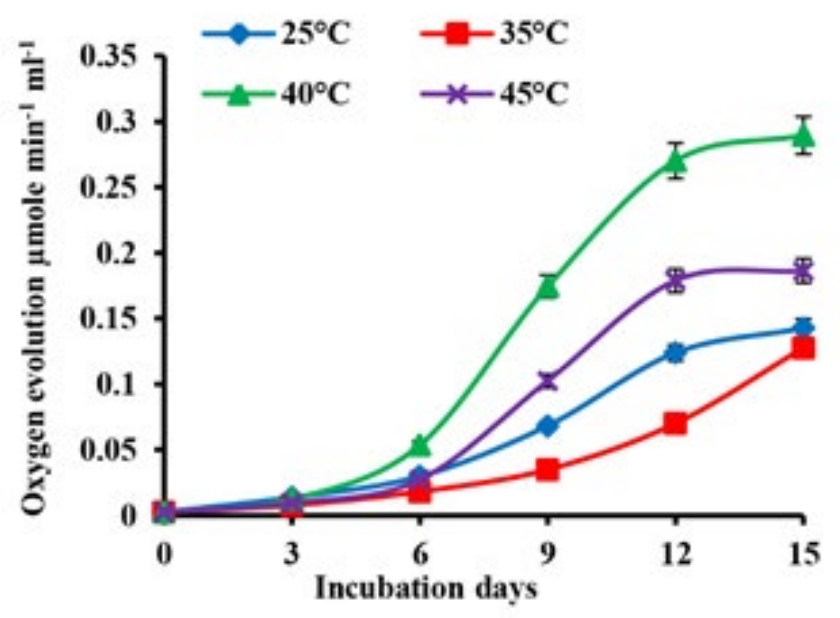

Fig. 3. Effects of differential temperature conditions on net oxygen evolution in Anabaena iyengarii 17-SKD-2014. The net oxygen evolution is measured at room temperature (at $25 \pm 1{ }^{\circ} \mathrm{C}$ ) with a constant volume of $1 \mathrm{ml}$ of cyanobacterial culture on each day and expressed in $\mu \mathrm{mol} \mathrm{min} \mathrm{mL}^{-1}$. The error bars represent $\pm S D(n=3)$.
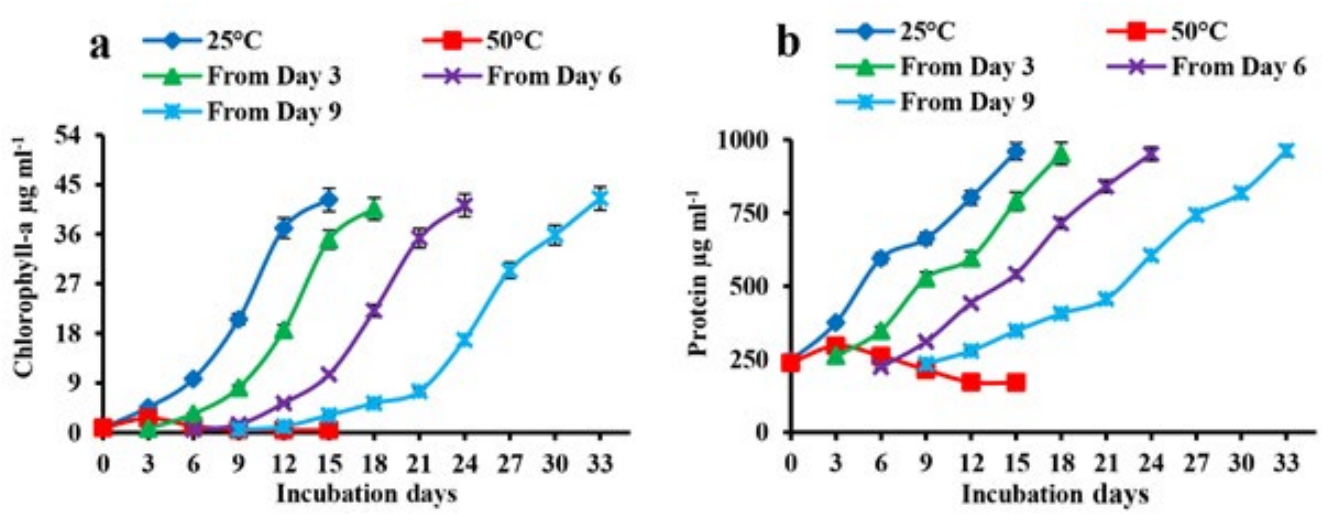

Fig. 4. Regeneration ability of heat-exposed cells/filaments of Anabaena iyengarii $17-S K D-2014$ at $50^{\circ} \mathrm{C}$ from the $3 \mathrm{rd}$ to 15 th days. (a) The regeneration potential of chlorophyll-a content, (b) total protein present in the sample for the respective days. Cyanobacterial isolates grown at $25^{\circ} \mathrm{C}$ and $50^{\circ} \mathrm{C}$ were both considered control groups. The line graph shows only three treated groups collected from the $3 \mathrm{rd}, 6$ th and 9 th day heat-stressed cultures, and because the 12th day samples were totally bleached, it has not been plotted here. All the values are the representation of three independent experiments \pm S.D. 
some of the soil- $\mathrm{N}_{2}$-fixing cyanobacteria present in paddy fields might have escaped the heat stress. An earlier report revealed that cyanobacteria can survive in soil temperatures around $50^{\circ} \mathrm{C}$ for a long duration ${ }^{27}$. In the present study, only 12 cyanobacterial species isolated from paddy field soils of Western Odisha could survive under high temperature $\left(45^{\circ} \mathrm{C}\right)$ continuously for 15 days. These cyanobacterial species belong to four different genera, namely Anabaena, Nostoc, Calothrix, and Hapalosiphon, which signifies that heat tolerance is highly species-specific and is not consigned to any single genus. The possible reason for the other isolates not being able to survive at $45^{\circ} \mathrm{C}$ may be because of their susceptibility to continuous wet heat conditions for a long duration. It was earlier reported that Scytonema millei, on exposure to different temperatures, was more sensitive to wet heat than dry heat state ${ }^{28}$. The four selected isolates, of which three species belong to the Nostoc genus and the other one to the Anabaena genus, when treated with different temperatures show maximum growth at $40^{\circ} \mathrm{C}$. Cyanobacteria are phototrophic and photosynthetic bacteria that significantly modulate their growth in natural habitats. A. iyengarii has been used in the present study to examine further its photosynthetic response to different temperatures under constant illumination in the laboratory. It is important to note that the contents of photosynthetic pigments like chlorophyll, phycobiliproteins and oxygen evolution show a distinct lag phase for the first six days of the incubation of the cyanobacteria with their subsequent slow and gradual rise up to 15 days of the incubation period. On the other hand, the total protein and total carotenoids content exhibits a slow climb from the beginning without any lag. Presently, it is difficult to explain the lag in photosynthetic pigments and oxygen evolution. The slowdown in oxygen evolution may be correlated with the lack of photosynthetic pigments ${ }^{29}$. On the other hand, an increase in the content of proteins and carotenoids without lag phase may indicate that their contents may be non-specific to photosynthetic activity.

The appearance of carotenoids from the beginning of the cyanobacterial growth may help the organism to counter the oxidative cellular environment before the appearance of the photosynthetic capacity ${ }^{30}$. The lack of the appearance of photosynthetic capacity at the initial phase of cyanobacterial growth appears to be independent of temperature because a change in the temperature of the culture did not have any effect on the lag characteristics.

Although cyanobacteria are known to survive and grow at a high-temperature range in different natural habitats, the survival, and sustenance of four species of cyanobacteria grown in laboratory conditions at $50^{\circ} \mathrm{C}$ are exhibited only for a limited period. Cyanobacteria have grown at the incubation temperature of $50^{\circ} \mathrm{C}$ sustain the viability for recovery on transferring to $25^{\circ} \mathrm{C}$ in the laboratory only for a short period. The viability, survival, and recovery of cyanobacteria are measured using the protein content of the sample. It is important to note that the longer the incubation period at $50^{\circ} \mathrm{C}$, the relatively larger the time taken by cyanobacteria for recovery ${ }^{31}$. Retention of recovery potential is species-specific. The retention of viability at the high temperature and the total protein content and photosynthetic pigment recovery of $A$. iyengarii grown on transfer to $25^{\circ} \mathrm{C}$ in the laboratory. The data indicate that viability is lost if the cyanobacterium is cultured in the laboratory at high temperatures for a prolonged period. Although cyanobacteria can grow at high temperatures in natural environments, the less survival ability of the organism at $50^{\circ} \mathrm{C}$ in the laboratory beyond a time limit is not clearly understood. These organisms are known to develop adaptive survival mechanisms to environmental stress in field conditions. The cyanobacterial species tested possibly failed to develop effective mechanisms for adaptation to high-temperature stress monitored in laboratory conditions $^{32}$.

Therefore, from the presnt findings, it may be inferred that mass culturing of $A$. iyengarii like indigenous cyanobacterial species, which can overcome high-temperature stress, act like novel microorganisms for resolving global warming issues and mitigating environmental pollution.

\section{ACKNOWLEDGMENTS}

We would like to express our heartfelt thanks to Professor Uday Chand Biswal and Dr. Ritendra Mishra for critical reading and editing the 
manuscript. We would like to thank Berhampur University and Sambalpur University for providing the necessary facilities to carry out this work.

\section{CONFLICT OF INTEREST}

The authors declare that there is no conflict of interest.

\section{AUTHORS' CONTRIBUTION}

All authors listed have made a substantial, direct and intellectual contribution to the work, and approved it for publication.

\section{FUNDING}

This work was supported by the Defence Institute of High Altitude Research, DRDO, Govt. of India (Grant/Sanction letter no. 118/APE/DIHAR)

\section{DATA AVAILABILITY}

All datasets generated or analyzed during this study are included in the manuscript.

\section{ETHICS STATEMENT}

This article does not contain any studies with human participants or animals performed by any of the authors.

\section{REFERENCES}

1. Ward DM, Castenholz RW, Miller SR. Cyanobacteria in Geothermal Habitats. In Whitton B (ed.), Ecology of Cyanobacteria II, Springer, Dordrecht, Netherlands. 2012:39-63. doi: 10.1007/978-94-007-3855-3_3

2. Bhatnagar A, Makandar MB, Garg MK, Bhatnagar M. Community structure and diversity of cyanobacteria and green algae in the soils of Thar Desert (India). J Arid Environ. 2008;72(2):73-83.

3. Belnap J. Recovery rates of cryptobiotic soil crusts: inoculant use and assessment methods. Gr Basin Nat. 1993;53:89-95.

4. Toro M, Camacho A, Rochera C, et al. Limnological characteristics of the fresh-water ecosystems of Byers Peninsula, Livingston Island, in maritime Antarctica. Polar Biol. 2007;30(5):635-649. doi: 10.1007/s00300006-0223-5

5. Vallieres C, Retamal L, Ramlal P, Osburn CL, Vincent WF. Bacterial production and microbial food web structure in a large arctic river and the coastal Arctic Ocean. J Mar Syst. 2008;74(3-4):756-773. doi: 10.1016/j. jmarsys.2007.12.002

6. Hove PV, Vincent WF, Galand PE, Wilmotte A. Abundance and diversity of picocyanobacteria in high Arctic lakes and fjords. Algol Stud. 2008;126:209-227. doi: 10.1127/1864-1318/2008/0126-0209

7. Saha SK, Das R, Bora KN, Uma L. Biodiversity of epilithic cyanobacteria from fresh-water streams of Kakoijana reserve forest, Assam, India. Indian J Microbiol. 2007;47(3):219-232. doi: 10.1007/s12088-007-0043-5

8. Stanier RY, Cohen-Bazire G. Phototrophic prokaryotes: the Cyanobacteria. Annu Rev Microbiol. 1977;31:225274.

9. Nishiyama Y, Murata N. Revised scheme for the mechanism of photoinhibition and its application to enhance the abiotic stress tolerance of the photosynthetic machinery. Appl Microbiol Biotechnol. 2014;98(21):8777-8796. doi: 10.1007/s00253-0146020-0

10. Berry J, Bjorkman O. Photosynthetic response and adaptation to temperature in higher plants.Annu Rev Plant Physiol. 1980;31(1):491-543. doi: 10.1146/ annurev.pp.31.060180.002423

11. Borges N, Ramos A, Raven NDH, Sharp RJ, Santos H. Comparative study of the thermostabilizing properties of mannosylglycerate and other compatible solutes on model enzymes. Extremophiles. 2002;6(3):209-216. doi: 10.1007/s007920100236

12. Mikami K, Murata N. Membrane fluidity and the perception of environmental signals in cyanobacteria and plants. Prog Lipid Res. 2003;42(6):527-543. doi: 10.1016/S0163-7827(03)00036-5

13. Balogi Z, Torok Z, Balogh G et al. Heat shock lipid in cyanobacteria during heat/light-acclimation. Arch Biochem Biophys. 2005;436(2):346-354. doi: 10.1016/j.abb.2005.02.018

14. Aminaka R, Taira $Y$, Kashino $Y$, Koike $H$, Satoh $K$. Acclimation to the growth temperature and thermosensitivity of photosystem II in a mesophilic cyanobacterium, Synechocystis sp PCC6803. Plant Cell Physiol. 2006;47(12):1612-1621. doi: 10.1093/pcp/ pcl024

15. Murata N, Takahashi S, Nishiyama Y, Allakhverdiev SI. Photoinhibition of photosystem Il under environmental stress. Biochim Biophys Acta. 2007;1767(6):414-421. doi: 10.1016/j.bbabio.2006.11.019

16. Inoue N, Taira Y, Emi T et al. Acclimation to the growth temperature and the high-temperature effects on photosystem II and plasma membranes in a mesophilic cyanobacterium, Synechocystis sp PCC6803. Plant Cell Physiol. 2001;42(10):1140-1148. doi: 10.1093/pcp/ pce147

17. Torok Z, Goloubinoff P, Horvath I et al. Synechocystis HSP17 is an amphitropic protein that stabilizes heatstressed membranes and binds denatured proteins for subsequent chaperone-mediated refolding. Proc Natl Acad Sci USA. 2001;98(6):3098-3103. doi: 10.1073/ pnas. 051619498

18. Tandeau de Marsac N, Houmard J. Adaptation of cyanobacteria to environmental stimuli: new steps towards molecular mechanisms. FEMS Microbiol Lett. 1993;104(1-2):119-189. doi: 10.1111/j.15746968.1993.tb05866.x

19. Ramos JL, Gallegos MT, Marques S, Ramos-Gonzalez MI, Espinosa-Urgel M, Segura A. Responses of Gramnegative bacteria to certain environmental stressors. Curr Opin Microbiol. 2001;4(2):166-171. doi: 10.1016/ S1369-5274(00)00183-1

20. Marles-Wright J, Lewis RJ. Stress responses of bacteria. Curr Opin Struct Biol. 2007;17(6):755-760. doi: 
10.1016/j.sbi.2007.08.004

21. Singh RN. Role of Blue-Green Algae in Nitrogen Economy of Indian Agriculture. Indian Council of Agricultural Research, New Delhi. 1961.

22. Dey HS, Tayung K, Bastia AK. Occurrence of nitrogen -fixing cyanobacteria in local rice fields of Orissa, India. Ecoprint. 2010;17:77-85. doi: 10.3126/eco.v17i0.4120

23. Myers J, Kratz WA. Relation between pigment content and photosynthetic characteristics in a blue-green algae. J Gen Physiol. 1955;39(1):11-22. doi: 10.1085/ jgp.39.1.11

24. Bennett A, Bogorad L. Complementary chromatic adaptation in a filamentous blue-green algae. $J$ Cell Biol. 1973;58(2):419-435. doi: 10.1083/jcb.58.2.419

25. Lowry OH, Rosebrough NJ, Farr AL, Randall RJ. Protein measurement with the Folin phenol reagent. J Biol Chem. 1951;193(1):265-275.

26. Jiang H, Qiu B. Photosynthetic adaptation of a bloomforming cyanobacterium Microcystis aeruginosa (Cyanophyceae) to prolonged UV-B exposure. J Phycol. 2005;41(5):983-992. doi: 10.1111/j.15298817.2005.00126.x

27. Fay P, Fogg GE. Studies on nitrogen fixation by bluegreen algae. III. Growth and nitrogen fixation in Chlorogloea fritschii Mitra. Arch Mikrobiol. 1962;42:310-321.
28. Bruno L, Ficorlle I, Valentini F, Quici L, Keshari N, Adhikari SP. Characterization of phototrophic biofilms deteriorating Indian stone monuments, their response to heat stress and development of a non-invasive remediation strategy. In Rogerio-Candelera MA (ed.) Science, Technology and Cultural. London: Heritage, CRC Press, Taylor \& Francis Group, London. 2014:205210.

29. Fu F-X, Warner ME, Zhang Y, Feng $Y$, Hutchins DA. Effects of increased temperature and $\mathrm{CO} 2$ on photosynthesis, growth, and elemental ratios in marine Synechococcus and Prochlorococcus (cyanobacteria). J Phycol. 2007;43(3):485-496.

30. Zakar T, Laczko-Dobos H, Toth TN, Gombos Z. Carotenoids assist in cyanobacterial photosystem II assembly and function. Front Plant Sci. 2016;7:295. doi: 10.3389/fpls.2016.00295

31. Rajaram H, Kumar Apte S. Heat-shock response and its contribution to thermotolerance of the nitrogenfixing cyanobacterium Anabaena sp strain L-31. Arch Microbiol. 2003;179(6):423-429. doi: 10.1007/s00203003-0549-0

32. Mathur S, Agrawal D, Jajoo A. Photosynthesis: response to high temperature stress. J Photochem Photobiol B. 2014; 137:116-126. 